\title{
INDICATORS OF OXIDATIVE AND NITROSATIVE STRESS AND ACTIVITY OF ENZYMES OF NITRIC OXIDE METABOLISM IN RATS TREATED WITH 4-THIAZOLIDINONE DERIVATIVES POSSESSING ANTINEOPLASTIC ACTIVITY
}

\author{
L. I. KOBYLINSKA', R. R. PANCHUK², R. B. LESYK ${ }^{1}$, \\ B. S. ZIMENKOVSKY1, R. S. STOIKA ${ }^{2}$ \\ ${ }^{1}$ Danylo Halytsky Lviv National Medical University, Ukraine; \\ ${ }^{2}$ Institute of Cell Biology, National Academy of Sciences of Ukraine, Lviv; \\ e-mail:lesya8@gmail.com
}

\begin{abstract}
Principal ways of generation and function of free oxygen and nitrogen radical metabolites, as well as the ways of their bio-neutralization in rats treated with potential anticancer drugs have been discussed. Three isatin-pyrazoline 4-thiazolidinone conjugates - Les-3288, Les-3833 and Les-3882 - were selected as the most perspective antineoplastic agents. Since the reactive oxygen species (ROS) and reactive nitrogen species are responsible for negative side effects of many anticancer drugs, we measured the indicators of the oxidative and nitrosative stress and the activity of enzymes of the nitric oxide metabolism in blood of rats treated with such compounds. It was found that both Les-3833 and doxorubicin used as a positive control increased the level of specific indicators of the oxidative and nitrosative stress, while Les-3288 and Les-3882 did not cause a significant elevation in ROS content. There were no big changes in the activity of either iNO-synthase or NOreductase under the action of doxorubicin, while Les-3288 and Les-3882 induced a decrease in the activity of iNO-synthase, and Les-3288 induced a decrease in the activity of NO-reductase. Thus, the content of low molecular weight indicators of the oxidative and nitrosative stress in blood of rats is of higher informative value than the level of activity of enzymes of the nitric oxide metabolism at the action of such toxic agents as anticancer drugs. These indicators should be used for assessment of toxic damage of tissues and organs by the anticancer drugs.
\end{abstract}

Key words: 4-thiazolidinone, doxorubicin, free radical oxidation, reactive oxygen species, reactive nitrogen species, enzymes of nitric oxide metabolism.

G eneration of the reactive oxygen species (ROS) and reactive nitrogen species (RNS) by cells of tissues and organs is an important mechanism in pathogenesis and in defense of the organism against various pathological agents [1-3]. Several toxic substances induce the development of the oxidative and/or nitrosative stress that are characterized by a shift of the intracellular redox balance to higher levels of free radical oxidation (FRO) [4, 5]. The mammalian cells produce free radical metabolites of oxygen and nitrogen that might be involved in transferring the regulatory signals in targeted cells $[1,4,6]$. The relevant signaling molecules affect cellular metabolism and play a key role in non-specific immune defense against the pathogenic factors, including those appearing at cancer development [5-7].

The oxidative and nitrosative stresses are caused by an excessive generation of ROS and RNS or insufficient protection against their action. ROS and RNS are molecules containing unpaired electrons, that makes them exceptionally reactive to DNA, proteins and lipids [1, 4, 7]. The superoxide radical is formed as a by-product of different enzymatic reactions, including cellular respiration, and it is converted into the hydroxyl radical in Fenton reaction catalyzed by the ions of transition metals such as copper and iron. Hydroxyl radical

(c) 2017 Kobylinska L. I. et al. This is an open-access article distributed under the terms of the Creative Commons Attribution License, which permits unrestricted use, distribution, and reproduction in any medium, provided the original author and source are credited. 
is primarily responsible for DNA damage and lipid peroxidation. The RNS arise from the regulated production of 'NO from L-arginine by NO-synthase. In combination with $\mathrm{O}_{2}^{-{ }^{-}}$NO forms the highly toxic peroxynitrite anion $\left(\mathrm{ONOO}^{-}\right)$, which causes DNA fragmentation, lipid peroxidation and protein modification $[7,8]$.

Studies conducted in the last decades demonstrated that the nitrogen oxide ( $\mathrm{NO}$ ) is a universal regulator with a wide range of biological effects [4]. It can improve the endothelial functions of the peripheral vessels, positively influences the activity of certain protein kinases, can serve as an inhibitor of caspases, and inhibits the induction of apoptosis in different types of cells [4]. At the same time, high concentrations of "NO can lead to a nitrosative stress caused by the action of the RNS, especially peroxynitrite and its cleavage product - nitrogen dioxide $[4,9]$. Application of doxorubicin leads to an increased expression of inducible NO-synthase in the myocardium [4]. This, in turn, causes hyperproduction of ' $\mathrm{NO}$ that reacts with superoxide anion radical and peroxynitrite - a powerful pro-oxidant capable of oxidating and nitrosating proteins, lipids and nucleic acids $[4,9]$. These data demonstrate a significant role of processes related to NO metabolism, including its synthesis and use by various types cells in norm and pathology.

Many chemotherapeutic agents act by raising cellular level of ROS that blocks growth of tumor cells and leads to their apoptosis [10-12]. Both the pro- and anti-apoptotic factors use FRO-modulated pro- and anti-oxidant mechanisms for killing both normal and tumor cells [11, 12]. New antineoplastic strategy based on differential induction of FROdependent mechanisms in normal and tumor cells has been proposed $[1,11,13]$. It should be noted that the use of most existing therapies in oncology is accompanied by the development of harmful effects of FRO on the cells of normal tissues and organs [1, $5,6,11-13]$. These negative side effects are mostly caused by ROS and RNS that significantly limits the applied dosage of appropriate anticancer drugs [1, 5, $6,12,14]$. Therefore, the oxidation-reduction balance in cells is an important biochemical target at the elimination of tumor cells. For efficient use of anticancer drugs, it is necessary to identify the molecular targets of FRO in tumor cells and find out which cellular functions are affected by ROS and RNS.

The aim of our study was to measure the content of metabolites of the oxidative and nitrosative stress, as well as the activity of enzymes of nitric oxide metabolism in blood serum of laboratory rats treated with 4-thiazolidinone derivatives that were previously studied at the National Cancer Institute (USA) within DPT program [15]. Cytotoxicity of the above mentioned compounds towards 60 human tumor cell lines has been evaluated, and three compounds (Les-3288, Les-3833 and Les-3882) possessing high cytotoxic action towards tumor cells were selected for more detailed analysis of the perspectives of their use as the antineoplastic agents. Studies of the biochemical mechanisms of their cytotoxic effects in vitro have been started, and their biocompatibility in vivo has been evaluated [13, 14, 16]. The results of such study will contribute to a better understanding of the ways of circumventing negative side effects by the oxidative stress appearing at the action of anticancer drugs with maximum preserving of their therapeutic efficacy.

\section{Materials and Methods}

The heterocyclic 4-thiazolidinones derivatives (Les-3288, Les-3882 and Les-3833) were synthesized as described earlier $[15,17]$. These compounds were dissolved in the dimethylsulfoxide (DMSO, Arterium, Ukraine), and then additionally dissolved in the distilled water before use. The final concentration of the DMSO in cell culture medium was below $0.1 \%$. Doxorubicin was purchased from Pfizer (Italy) representative in Ukraine

All experiments with white laboratory Vistar rats were conducted under the control of the BioEthics Committee at Danylo Halytsky Lviv National Medical University (Protocol N4 of 18.04.2016). Matured white laboratory rats with body mass of 180-220 g were kept on a standard feed in animal facility with adequate lighting and temperature conditions. The rats had access to water $24 \mathrm{~h}$ a day.

The studied agents were administered to animals every day in the morning before the first meal. Such a mode of administration is common for preclinic studies experimental medicines [18]. The experiment lasted for 10 days for animals that received doxorubicin and for 20 days for animals that received the synthetic compounds with the anticancer potential. Doxorubicin was injected starting from the dose of $5.5 \mathrm{mg} / \mathrm{kg}$, the compounds Les-3882 and Les-3833 - starting from the dose of $10.7 \mathrm{mg} / \mathrm{kg}$, and the compound Les-3288 - starting from the dose of $24.3 \mathrm{mg} / \mathrm{kg}$. The starting dose equaled $10 \%$ of maxi- 
mum injected dose in the experiments performed for $\mathrm{LC}_{50}$ determination [18]. The dose was gradually elevated 1.5 times for 4 days to achieve the cumulative effect. The experimental groups used in the study were as follows: $1-$ control $(n=20) ; 2-$ doxorubicin injection as positive control $(n=20) ; 3$ - Les-3288 injection $(n=20)$; 4 - Les-3882 injection $(n=20)$; 5 - Les-3833 injection $(n=20)$. On the $10^{\text {th }}$ or $20^{\text {th }}$ day of the experiment, the rats were euthanized by decapitation under the thiopental anesthesia [18]. Blood was taken and used to separate serum.

Measurement of indicators of oxidative and nitrosative stress in blood serum of treated rats. The content of generated $\mathrm{O}_{2}^{--}$.was measured by the oxidation of the cytochrom c (Sigma, USA) and defined as an optical density at $550 \mathrm{~nm}$ [19]. The content of 'OH radical was measured in the incubation medium with 2-deoxy-D-ribose (Sigma, USA) and defined by an absorption at $532 \mathrm{~nm}$ as an elevation in the content of the malonic dialdehyde [20]. The means of both indicators are presented as the arbitrary units of changed extinction per $1 \mathrm{~min}$ in $1 \mathrm{ml}$ of blood serum. $\mathrm{H}_{2} \mathrm{O}_{2}$ content was measured as described in [21]. The level of the nitrate anion $\left(\mathrm{NO}_{3}{ }^{-}\right)$was determined by a spectrophotometric method [22] - a modified brucine method for determination of nitrate. The activity of inducible NO-synthase (iNOS) was measured by using the colorimetric method for the newly synthesized nitrite anion [23]. The measurement of NO-reductase activity was carried out by the detection of its substrate - nitrate anion [24].

Measurement of ROS in treated human glioma U251 cells. ROS were measured by the activated fluorescence analysis using FACS cell sorter machine (BD Biosciences, Mountain View, CA). ROS content in cells was measured after their staining with fluorescent dye dihydroethidum (DHE, $\mathrm{O}_{2}^{-}$-specific dye) incubating the control (untreated) and drug-treated (6, 12, 24 h) cells. Glioma U251 cells were pre-incubated three times with the DHE $(10 \mu \mathrm{M})$ for $30 \mathrm{~min}$ at $37^{\circ} \mathrm{C}$ before their measurement at FL2 channel of the FACSCalibur flow cytometer (BD Biosciences, San Jose, CA, USA).

Data analysis and statistics. All experiments were repeated three times with three parallels in each variant. The Analysis of Variance (ANOVA) was used as statistics test for comparison of groups. All data are presented as a mean $\pm \mathrm{SD}$. The results were analyzed using GraphPad Prism 6 software. Statistical analysis was performed using $t$-test or two-way ANOVA. To examine differences between drug treatment responses, Bonferroni post-tests were conducted. $P$ values below 0.05 were considered as statistically significant and marked with stars: ${ }^{*} P<0.05$; *** $P<0.01$.

\section{Results and Discussion}

An increase in FRO is caused by the imbalance between the production of ROS and RNS as well as the ability of cells to restore the oxidative damage of the biological system or neutralize free radicals [1]. The activation of FRO leads to a pathological process causing the frequent intoxication of the organism $[13,14]$. The results of studying the effect of experimental compounds (4-thiazolidinone derivatives - Les-3288, Les-3833 and Les-3882) on ROS and RNS concentration in blood serum of rats are shown on Fig. 1-4. It is known that superoxide anion radical $\left(\mathrm{O}_{2}{ }^{-}\right)$and hydroxyl radical $\left({ }^{\circ} \mathrm{OH}\right)$ are the most powerful triggers of FRO reactions, since they can interact with nitrogen oxides that leads to formation of highly toxic peroxynitrite (Fig. 1) [4]. We have found that the administration of Les-3288 that leads to the $46 \%$ reduction in $\mathrm{O}_{2}{ }^{--}$concentration in blood serum of the treated rats, whereas Les-3833 and doxorubicin did not affect the content of $\mathrm{O}_{2}{ }^{--}$. Doxorubicin increased 2.2 times the content of the hydroxyl radical, while 4-thiazolidinone derivatives were reduced 2-3 times.

Doxorubicin and Les-3833 increased hydrogen peroxide twice, and Les-3288 and Les-3882 did not decrease it significantly (Fig. 2). Besides, doxorubicin increased 2.5 times the pool of the nitrate anion (indicator of the nitric oxide measured by Griess method), and Les-3833 increased it by $60 \%$, whereas Les-3288 and Les-3882 lowered the concentration of $\mathrm{NO}_{3}^{-}$by $30 \%$ (Fig. 2).

The activities of the inducible NO-synthase and NO-reductase were reduced twice under the action of the Les-3288 and by $35 \%$ - under the action of Les3882, while doxorubicin and Les-3833 did not affect the activity of these enzymes significantly (Fig. 3). The inducible NO-synthase and NO-reductase are responsible for the production of nitrogen oxide $[4,9]$, while NO-synthase provides an endogenous synthesis of ${ }^{\circ} \mathrm{NO}$ that is then oxidized to nitrite and nitrate anions, the NO-reductase converts the nitrate ions into the nitrite that is transformed into the ${ }^{\mathrm{NO}}$ due to a lack of oxygen. This mechanism is known as the "nitric oxide cycle" [4, 9]. If cells have enough ${ }^{-} \mathrm{NO}$ and $\mathrm{O}_{2}^{-}$, then the peroxynitrite is synthesized. The relatively non-toxic nitrate anion is the major 


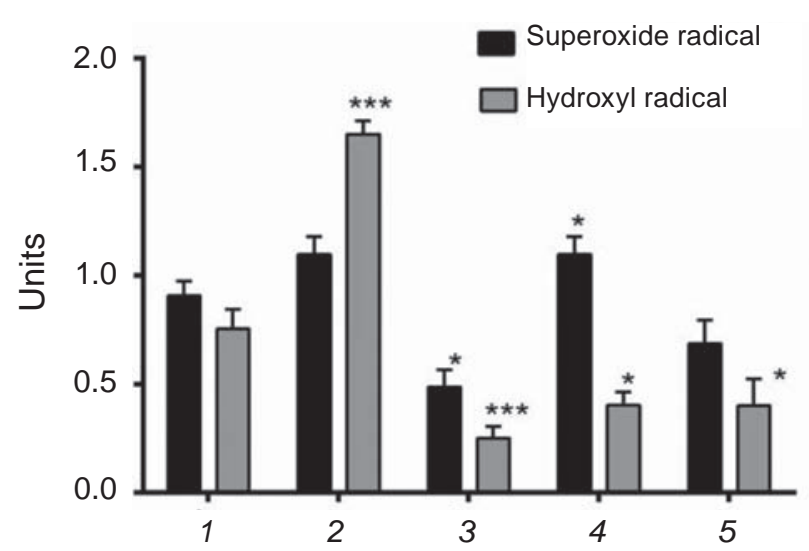

Fig. 1. Concentrations of superoxide radical and hydroxyl radical in blood serum of rats treated: 1 - control, 2 - doxorubicin, 3 - Les-3288, 4 - Les-3833, 5 - Les-3882. Here and on Fig. 1-4 $* P \leq 0.05 ; * * * P \leq 0.01$ (difference compared to control)

metabolite of the nitric oxide that circulates in the body. Its oxygen atoms originate from two metabolic pathways of FRO - both the nitrosative and oxidative $[1,2]$. Thus, an increased content of $\mathrm{NO}_{3}^{-}$might be an indicator of the oxidative processes, and it suggests the presence of the nitrosative stress in the circulating blood of animals treated with the anticancer drugs. Doxorubicin and Les-3833 caused an elevation in the content of the nitrate anion that reacts with the superoxide radicals forming the peroxynitrite. Evidently this was the reason why there was no increase in the content of $\mathrm{O}_{2}{ }^{--}$which could be rapidly used in the above mentioned reaction.

There are two ways of the peroxynitrite decomposition: 1) with forming the nitrate anion, and

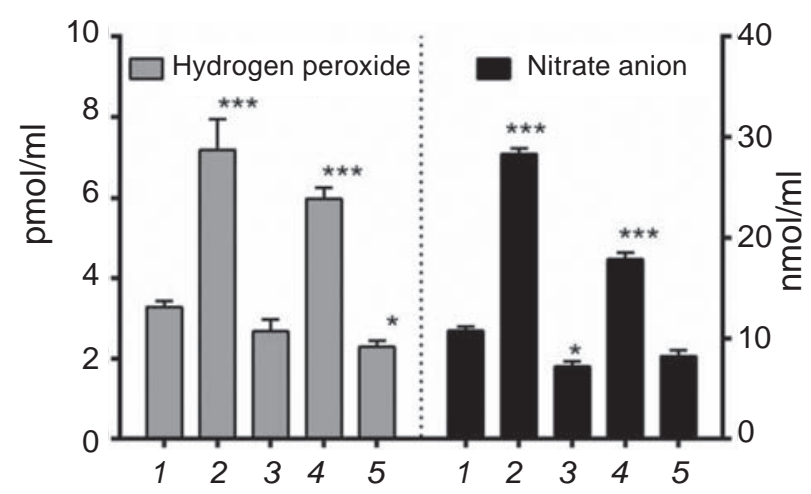

Fig. 2. Concentrations of hydrogen peroxide and nitrate anion in blood serum of rats treated: 1 - control, 2 -doxorubicin, 3 -Les-3288, 4 - Les-3833, 5 - Les-3882

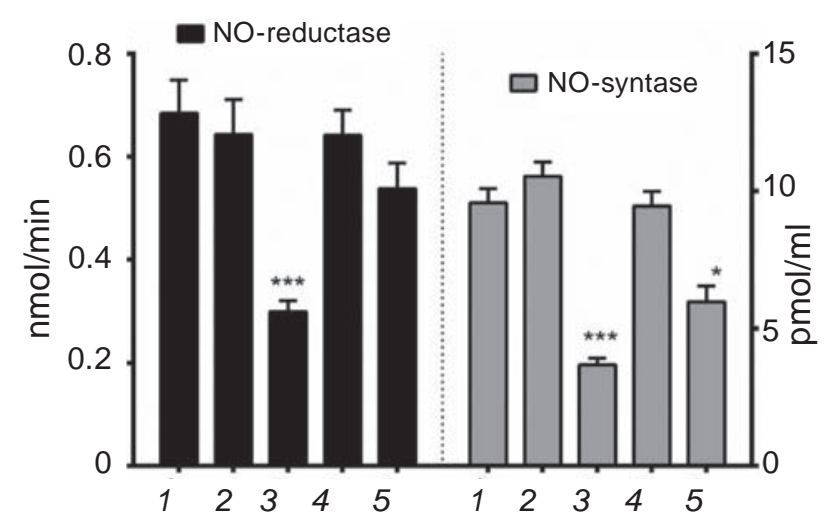

Fig. 3. Activity of NO-syntase and NO-reductase in blood serum of rats treated: 1 -control, 2 -doxorubicin, 3 - Les-3288, Les-3833, 4 - Les-3882

2) with production of ROS, particularly the hydroxyl radical. Thus, the nitrate anion can be also considered as a marker of the nitrosative stress [9]. The NOreductase restores the nitrite and nitrate anions to NO. However, we did not find a significant increase in the activity of studied enzymes in blood serum of rats of the experimental groups, on the contrary, in some cases (the action of Les-3288 and Les-3882), a decline in activity was detected. Obviously, an increase in content of the nitrate anion was caused by its release from a deposition of the $\mathrm{NO}$. Thus, a formation of excess ${ }^{\circ} \mathrm{NO}$, nitrosothiols, nitrosylation of glutathione, and appearance of the hydrogen sulfide involving $\mathrm{SH}$-groups of cysteine could be important at the action of anticancer agents under study $[4,9]$. The "reserves" of 'NO release might be activated at extreme conditions, like the effect of the anticancer drugs [9].

The less toxic compound Les-3288 was used in determining the level of ROS in human glioma U251 cells (Fig. 4). Neither Les-3288, nor temozolomide (TMZ) that is widely used for glioma treatment affected the ROS level measured by FACS analysis of the dihydroethidium (DHE) dye in these glioma cells treated for 6-24 h. This dye is known to be an $\mathrm{O}_{2}{ }^{--}$-specific one. However, doxorubicin induced relatively rapid (6 h) elevation of ROS concentration which was then diminished during further (12-24 h) cell treatment.

Thus, both the doxorubicin and 4-thiazolidinone derivative 3833 could realize their cytotoxic action via the induction of the nitrosative and oxidative stresses. The ROS and RNS can serve as important biomarkers for evaluating the efficacy of the action of innovative anticancer agents based on their cyto- 


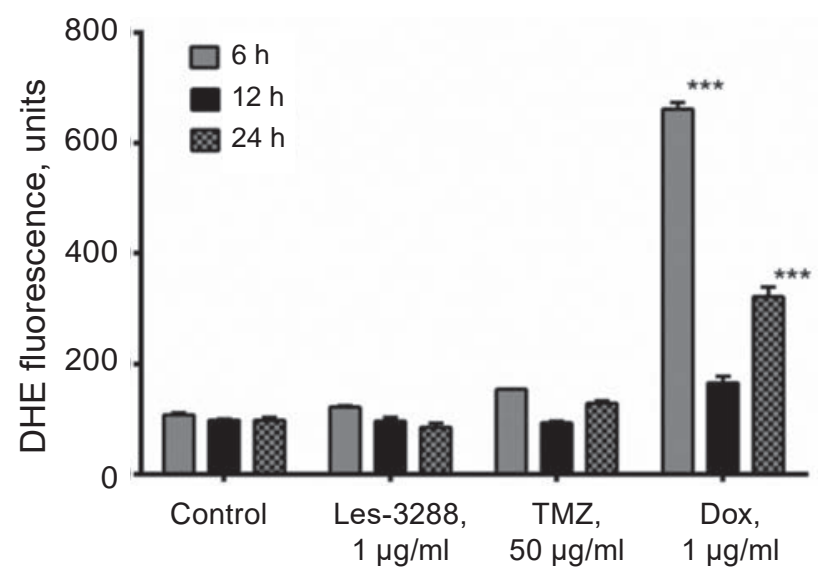

Fig. 4. The results of FACS analysis of ROS level in human glioma U251 cells treated with the 4-thiazolidinone derivative Les-3288, doxorubicin (Dox) and temozolomide (TMZ)

toxicity. The redox balance in the treated mice and the effectiveness of the compensatory FRO system aimed at maintaining the normal level of ROS and RNS production might protect the organism from the negative side effects of the anticancer drugs that appear due to their general toxicity and damaging cells of normal tissues and organs of cancer patients.

In vitro evaluation of the vitality and survival (MTT assay and Trypan blue exclusion test) of treated cells revealed the following ranking of toxicity of 4-thiazolidinone derivatives towards C6 rat and U251 human glioma cells: $3882<3288<3833 \approx$ doxorubicin $[14,25]$. In vivo study (rats) of the biochemical indicators of cardio- [26], hepato- [13] and nephrotoxic [27] actions of the applied drugs showed the same ranking. In this study, we have found that the increased level of ROS and RNS in blood serum of the experimental rats also demonstrated similar ranking. This suggests that general toxicity of these drugs is in some way related to their ability to induce production of ROS and RNS. We suggest that an optimal balance between the anticancer activity of traditional and experimental drugs and their effects on the concentration of ROS and RNS is important. Proper modulation of the level of anticancer druginduced ROS and RNS might be a useful strategy to decrease negative consequences of toxic effects of most anticancer drugs in the treated organism.

\section{ПОКАЗНИКИ ОКСИДАТИВНОГО I НІТРОЗАТИВНОГО СТРЕСУ ТА АКТИВНІСТЬ ЕНЗИМІВ МЕТАБОЛІЗМУ ОКСИДУ АЗОТУ В ЩУРІВ ЗА ДІЇ ПОХІДНИХ 4-ТІАЗОЛІДИНОНУ ІЗ ПРОТИПУХЛИННОЮ АКТИВНІСТЮ}

\author{
Л. І. Кобилінська ${ }^{1}$, Р. Р. Панчук ${ }^{2}$, \\ Р. Б. Лесик ${ }^{1}$ Б. С. Зіменковський \\ P. С. Стойка ${ }^{2}$
}
${ }^{1}$ Львівський національний медичний університет імені Данила Галицького, Україна;
${ }^{2}$ Інститут біології клітини НАН України, Львів; e-mail: lesya8@gmail.com

У роботі обговорено основні шляхи формування і функції вільнорадикальних метаболітів кисню та азоту, а також способи їх біологічної нейтралізації в крові щурів за дії потенційних протипухлинних препаратів. Три похідних 4-тіазолідинону - Les-3288, Les-3833 i Les3882 - були вибрані нами як найперспективніші протипухлинні агенти. Оскільки активні форми кисню (АФК), а також активні форми нітрогену відповідальні за негативні побічні ефекти багатьох протиракових лікарських засобів, було виміряно показники оксидативного i нітрозативного стресу та активність ензимів обміну окису азоту в крові щурів за дії досліджуваних сполук. Встановлено, що Les3833 і доксорубіцин, який використовували як позитивний контроль, підвищували рівень показників оксидативного i нітрозативного стресу, в той час, як сполуки Les-3288 i Les-3882 не спричинювали зростання рівня АФК. Також не спостерігали значних змін в активності іNOсинтази й NO-редуктази за дії доксорубіцину, в той час, як препарати Les-3288 i Les-3882 знижували активність iNO-синтази, a Les-3288 знижував до того ж активність NO-редуктази. Таким чином, вміст радикальних показників оксидативного і нітрозативного стресу $є$ інформативнішим, ніж рівень активності ензимів обміну окису азоту в крові досліджуваних щурів за впливу таких токсичних речовин як протипухлинні сполуки. Одержані показники можуть бути використані для оцінки токсичного пошкодження тканин та органів за дії протипухлинних препаратів. 
Кл юч ов і слова: 4-тіазолідинони, доксорубіцин, вільнорадикальне окислення, активні форми кисню, активні форми азоту, ензими метаболізму оксиду азоту.

\section{ПОКАЗАТЕЛИ ОКСИДАТИВНОГО И НИТРОЗАТИВНОГО СТРЕССА И АКТИВНОСТЬ ЭНЗИМОВ МЕТАБОЛИЗМА ОКСИДА АЗОТА У КРЫС ПОД ДЕЙСТВИЕМ ПРОИЗВОДНЫХ 4-ТИАЗОЛИДИНОНА С ПРОТИВООПУХОЛЕВОЙ АКТИВНОСТЬЮ}

\section{Л. И. Кобылинская ${ }^{1}$, Р. Р. Панчук², \\ Р. Б. Лесик ${ }^{1}$ Б. С. Зименковский \\ P. С. Стойка ${ }^{2}$}

\author{
${ }^{1}$ Львовский национальный медицинский \\ университет имени Данила Галицкого, Украина; \\ ${ }^{2}$ Институт биологии клетки НАН Украины, Львов; \\ e-mail: lesya8@gmail.com
}

В роботе обсуждены основные пути формирования и функции свободнорадикальных метаболитов кислорода и азота, а также способы их биологической нейтрализации в крови крыс при действии потенциальных противоопухолевых препаратов. Три производных 4-тиазолидинона - Les-3288, Les-3833 и Les-3882 - были выбраны нами как наиболее перспективные противоопухолевые агенты. Поскольку активные формы кислорода (АФК), а также активные формы азота ответственны за негативные побочные эффекты многих противораковых лекарственных средств, мы определяли влияние исследуемых соединений на показатели оксидативного и нитрозативного стресса и активность энзимов обмена оксида азота в крови крыс. Установлено, что Les-3833 и доксорубицин, использованный нами в качестве положительного контроля, повышал уровень показателей оксидативного и нитрозативного стресса, в то время, как соединения Les-3288 и Les-3882 не вызывали повышения уровня АФК. Также не наблюдалось значительных изменений в активности iNO-синтазы и NO-редуктазы под действием доксорубицина, в то время, как препараты Les-3288 и Les-3882 снижали активность iNO-синтазы, a Les-3288 к тому же снижал активность NO-редуктазы. Таким образом, содержание свободнорадикальных показателей оксидативного и нитрозативного стресса можно считать более информативными, чем уровень активности энзимов обмена оксида азота в крови исследуемых крыс под действием таких токсичных веществ как противоопухолевые препараты. Полученные показатели могут быть использованы для оценки токсического повреждения тканей и органов при действии противоопухолевых препаратов.

Кл ю че вы е с лов в: 4-тиазолидиноны, доксорубицин, свободнорадикальное окисление, активные формы кислорода, активные формы азота, энзимы метаболизма оксида азота.

\section{References}

1. Yang Y, Karakhanova S, Werner J, Bazhin AV. Reactive oxygen species in cancer biology and anticancer therapy. Curr Med Chem. 2013; 20(30): 3677-3692.

2. Varga ZV, Ferdinandy P, Liaudet L, Pacher P. Drug-induced mitochondrial dysfunction and cardiotoxicity. Am J Physiol Heart Circ Physiol. 2015; 309(9): H1453-H1467.

3. K V A, Madhana RM, Kasala ER, Samudrala PK, Lahkar M, Gogoi R. Morin Hydrate Mitigates Cisplatin-Induced Renal and Hepatic Injury by Impeding Oxidative/Nitrosative Stress and Inflammation in Mice. $J$ Biochem Mol Toxicol. 2016; 30(12): 571-579.

4. Burlaka AP, Sydoryk EP. The radical oxygen and nitrogen species in cancer. K.: Nauk. Dumka, 2006. 228 p. (In Ukrainian).

5. Cherepenko EI. Molecular protective mechanisms of cell and pharmacotherapy. K.: Nauk. Dumka, 2012. 264 p. (In Ukrainian).

6. Manda G, Nechifor MT, Neagu TM. Reactive Oxygen Species, Cancer and Anti-Cancer Therapies. Curr Chem Biol. 2009; 3(1): 322-346.

7. Fatima S, Al-Mohaimeed N, Al-Shaikh Y, Tyagi P, Banu N, Hasan S, Arjumand S. Combined treatment of epigallocatechin gallate and Coenzyme Q10 attenuates cisplatin-induced nephrotoxicity via suppression of oxidative/ nitrosative stress, inflammation and cellular damage. Food Chem Toxicol. 2016; 94: 213-220.

8. Townsend DM, Manevich Y, He L, Hutchens S, Pazoles CJ, Tew KD. Novel role for glutathione S-transferase pi. Regulator of protein S-Glutathionylation following oxidative and nitrosative stress. $J$ Biol Chem. 2009; 284(1): 436-445. 
9. Akopova OV, Korkach YuP, Kotsuruba AV, Kolchiynskaya LI, Sagach VF. Reactive nitrogen and oxygen species metabolism in rat heart mitochondria upon administration of NO donor in vivo. Fiziol Zh. 2012; 58(2): 3-15. (In Ukrainian).

10. Gorrini C, Harris IS, Mak TW. Modulation of oxidative stress as an anticancer strategy. Nat Rev Drug Discov. 2013; 12(12): 931-947.

11. Matés JM, Sánchez-Jiménez FM. Role of reactive oxygen species in apoptosis: implications for cancer therapy. Int J Biochem Cell Biol. 2000; 32(2): 157-170.

12. Tong L, Chuang CC, Wu S, Zuo L. Reactive oxygen species in redox cancer therapy. Cancer Lett. 2015; 367(1): 18-25.

13. Kobylinska LI, Havrylyuk DYa, Ryabtseva AO, Mitina NE, Zaichenko OS, Lesyk RB, Zimenkovsky BS, Stoika RS. Biochemical indicators of hepatotoxicity in blood serum of rats under the effect of novel 4-thiazolidinone derivatives and doxorubicin and their complexes with polyethyleneglycol-containing nanoscale polymeric carrier. Ukr Biochem J. 2015; 87(2): 122-132.

14. Kobylinska LI, Boiko NM, Panchuk RR, Grytsyna II, Klyuchivska OYu, Biletska LP, Lesyk RB, Zimenkovsky BS, Stoika RS. Putative anticancer potential of novel 4-thiazolidinone derivatives: cytotoxicity towards rat C6 glioma in vitro and correlation of general toxicity with balance of free radical oxidation in rats. Croat Med J. 2016; 57(2): 150-163.

15. Havrylyuk D, Zimenkovsky B, Vasylenko O, Gzella A, Lesyk R. Synthesis of new 4-thiazolidinone-, pyrazoline-, and isatin-based conjugates with promising antitumor activity. J Med Chem. 2012; 55(20): 8630-8641.

16. Kobylinska L, Havrylyuk D, Patereha I, Kotsyumbas I, Lesyk R, Stoika R. Study of acute toxicity and cumulative properties in rats of novel synthetic 4-tiazolidone derivatives with potential antineoplastic activity. Modern Probl Toxicol Food Chem Safety. 2013; 4(63): 38-43. (In Ukrainian).

17. Patent UA u201114202, N69857. 3-\{2-[5-(3,5diaryl)-4,5-dihydropyrazol-1-yl]-4-oxo-4Hthiazol-5-iliden\}-1,3-dihydroindol-2-ones, that possess anticancer activity / Havrylyuk DYa, Zimenkovsky BS, Lesyk RB, Roman OM. Publ. 10.05.2012, Bull. N 19. (In Ukrainian).

18. Stefanov OV. Preclinical Studies of Medicines. Methodol. Recomm. 2001. 527 p. (In Ukrainian).
19. Kuthan H, Ullrich V, Estabrook RW. A quantitative test for superoxide radicals produced in biological systems. Biochem J. 1982; 203(3): 551-558.

20. Conte D, Narindrasorasak S, Sarkar B. In vivo and in vitro iron-replaced zinc finger generates free radicals and causes DNA damage. J Biol Chem. 1996; 271(9): 5125-5130.

21. Huwiler $\mathbf{M}$, Kohler $H$. Pseudo-catalytic degradation of hydrogen peroxide in the lactoperoxidase $/ \mathrm{H}_{2} \mathrm{O}_{2}$ /iodide system. Eur $J$ Biochem. 1984; 141(1): 69-74.

22. Tsukahara H, Miura M, Tsuchida S, Hata I, Hata K, Yamamoto K, Ishii Y, Muramatsu I, Sudo M. Effect of nitric oxide synthase inhibitors on bone metabolism in growing rats. $\mathrm{Am} J$ Physiol. 1996; 270(5 Pt 1): E840-E845.

23. Bredt DS, Snyder SH. Isolation of nitric oxide synthetase, a calmodulin-requiring enzyme. Proc Natl Acad Sci USA. 1990; 87(2): 682-685.

24. Li H, Samouilov A, Liu X, Zweier JL. Characterization of the magnitude and kinetics of xanthine oxidase-catalyzed nitrite reduction. Evaluation of its role in nitric oxide generation in anoxic tissues. $J$ Biol Chem. 2001; 276(27): 24482-24489.

25. Kobylinska LI, Klyuchivska OY, Grytsyna II, Finiuk N, Panchuk RR, Starykovych MO, Lehka L, Lesyk RB, Zimenkovsky BS, Stoika RS. Differential pro-apoptotic effects of synthetic 4-thiazolidinone derivative Les-3288, doxorubicin and temozolomide in human glioma U251 cells. Croat Med J. 2017; 58(2): 150-159.

26. Kobylinska LI, Havrylyuk DYa, Ryabtseva AO, Mitina NE, Zaichenko OS, Zimenkovsky BS, Stoika RS. Study of rat blood serum biochemical indicators of cardiotoxic action of novel antitumor 4-thiazolidinone derivatives and doxorubicin in complexes with polyethylene glycol-containing polymeric carrier in the rat blood serum. $U k r$ Biochem J. 2014; 86(6): 84-95. (In Ukrainian).

27. Kobylinska LI, Havrylyuk DYa, Mitina NE, Zaichenko AS, Lesyk RB, Zimenkovsky BS, Stoika RS. Biochemical indicators of nephrotoxicity in blood serum of rats treated with novel 4-thiazolidinone derivatives or their complexes with polyethyleneglycol-containing nanoscale polymeric carrier. Ukr Biochem J. 2016; 88(1): 51-60.

Received 20.06.2017 